\title{
NEUROTOXIC EFFECT OF TITANIUM DIOXIDE NANOPARTICLES: BIOCHEMICAL AND PATHOLOGICAL APPROACH IN MALE WISTAR RATS
}

\section{VASANTHARAJA*, V. RAMALINGAM}

\author{
Department of Zoology, Kanchi Mamunivar Centre for Post Graduate Studies (Affiliated to Pondicherry University), Lawspet, Puducherry \\ 605008, India \\ Email: vasaini20@gmail.com
}

Received: 03 Mar 2018, Revised and Accepted: 24 May 2018

\section{ABSTRACT}

Objective: Titanium dioxide nanoparticles $\left(\mathrm{TiO}_{2} \mathrm{NPs}\right)$ are widely used in pharmaceutical, cosmeceutical, biomedical and industrial applications. The adverse effects of $\mathrm{TiO}_{2} \mathrm{NPs}$ are also increasing alarmingly. The purpose of this study is to investigate the toxicity of $\mathrm{TiO}_{2} \mathrm{NPs}_{\text {on }}$ biochemical and histological changes in different regions of brain in adult male Wistar rats.

Methods: Two different doses of $\mathrm{TiO}_{2} \mathrm{NPs}(50 \mathrm{mg} / \mathrm{kg} \mathrm{b.} \mathrm{w}$ and $100 \mathrm{mg} / \mathrm{kg} \mathrm{b.} \mathrm{w)} \mathrm{administered} \mathrm{orally} \mathrm{for} 14 \mathrm{~d}$ along with one control group, each group consisting of six animals. Standard biochemical methods were adopted for the estimation of enzymes alkaline phosphatase, 5' nucleotidase, ATPases and gamma-glutamyl transpeptidase. Trace elements calcium, sodium, potassium and magnesium as well as metals like iron, zinc and copper were also estimated.

Results: When compared with the control group, the enzymes ATPases, ALP, 5'-NT and GGT activities were significantly decreased in both the TiO 2 NPs treated groups. $\mathrm{Ca}, \mathrm{Na}, \mathrm{Fe}, \mathrm{Cu}$ and $\mathrm{TiO}_{2}$ contents were significantly increased in both the experimental groups, while the $\mathrm{K}, \mathrm{Mg}$ and $\mathrm{Zn}$ contents decreased. However, the changes in the parameters studied were more in $100 \mathrm{mg}$ treated group $(\mathrm{p}<0.001)$ when compared to the $50 \mathrm{mg}$ treated group $(p<0.05$ and $p<0.01)$. Moreover, it is also evident that different regions responded differently due to $\mathrm{TiO}_{2} \mathrm{NPs}$ exposure. The changes were maximum in the cerebral hemisphere $(\mathrm{p}<0.001)$ followed by medulla oblongata $(\mathrm{p}<0.001)$ and cerebrum $(\mathrm{p}<0.05)$.

Conclusion: The results clearly imply that $\mathrm{TiO}_{2} \mathrm{NPs}$ could impair the electrochemical gradient, ionic homeostasis and membrane stability in different regions of the rat brain.

Keywords: Nanoparticles, Titanium, Brain, Membrane enzymes, Trace metals

(C) 2018 The Authors. Published by Innovare Academic Sciences Pvt Ltd. This is an open access article under the CC BY license (http://creativecommons.org/licenses/by/4.0/) DOI: http://dx.doi.org/10.22159/ijap.2018v10i4.25622

\section{INTRODUCTION}

$\mathrm{TiO}_{2} \mathrm{NPs}$ is one of the most widely applied engineered nanoparticles in the nanotechnology field, where it is consequently used in paints, paper, plastics, ceramics, toothpaste, food colorants, drug capsule, catalysts and wastewater treatment $[1,2]$. The yearly production of $\mathrm{TiO}_{2} \mathrm{NPs}$ in 2002 was approximately 3,000 tons per annum, and is estimated to increase to 2.5 million metric tons annually by 2025 [3]. It is reported that in sunscreen and cosmetic products approximately $50 \%$ of $\mathrm{TiO}_{2}$ NPs are used [4]. It is evident from previous studies that less than $100 \mathrm{~nm}$ NPs have a high level of photocatalytic activity [5]. The unique characteristics of $\mathrm{TiO}_{2}$ particle is that it can enter the human body quickly and then imposes potential health risks on human $[6,7]$. The adverse toxic effects of $\mathrm{TiO}_{2} \mathrm{NPs}$ have been studied in several animal models like rats, mice, rabbits and human following exposure by multiple routes of administration, including whole-body exposure, dermal exposure, gastric lavage, and inhalation $[1,2,8,9]$. Few studies reported that inhaled or injected nanoparticles enter the systemic circulation and migrate to various parts to exert adverse effects $[10,11]$.

The effects of $\mathrm{TiO}_{2}$ NPs on hepatic and renal dysfunctions were demonstrated by several studies through the detection of different functional enzymes such as alanine aminotransferase (ALT) and aspartic aminotransferase (AST) [1, 12-15]. Our previous study in this laboratory also observed that $\mathrm{TiO}_{2}$ NPs significantly alter these enzymes affecting liver and kidney of rats [16]. Nanoparticles can cross the blood-brain barrier (BBB) and enter in the central nervous system (CNS) of the exposed animals [11, 17]. Dermal exposure of $\mathrm{TiO}_{2} \mathrm{NPs}$ could penetrate up to the brain via the skin as it was detected in the brain of mice [18]. $\mathrm{TiO}_{2}$ NPs could impair the short and long-term synaptic plasticity and also reactive oxygen species (ROS) mediated oxidative stress-induced damage and inflammatory response in rat brain [19]. $\mathrm{TiO}_{2} \mathrm{NPs}$ were also shown to stimulate excess ROS generation in the brain microglial cells and cause neuron damages [20].
CNS is a main target for various environmental pollutants and xenobiotic chemicals, including heavy metals and metal oxides. Airborne metal dust or fumes is a foremost way of occupational exposure, causing acute and chronic disorders such as metal fume fever and chronic obstructive pulmonary disease (COPD) [21]. Direct disruption of neuronal cell membranes by nanoparticles would allow their entry into the brain $[6,21,22]$. Membrane-bound enzymes such as alkaline phosphatase (ALP), 5' nucleotidase (5'-NT) and gamma-glutamyl transpeptidase (GGT) are predominantly concentrated in the vascular endothelium in the brain. Membrane ATPases are primary active transporters of cations that maintain a steep gradient and that form the basis for a range of essential cellular physiological processes. ATPase activity is an important toxicological tool to analyze the effect of xenobiotics.

Metal ions such as calcium $(\mathrm{Ca})$, sodium $(\mathrm{Na})$, potassium $(\mathrm{K})$, iron $(\mathrm{Fe})$, copper $(\mathrm{Cu})$, zinc $(\mathrm{Zn})$ and magnesium $(\mathrm{Mg})$ are vital to life and participate in numerous metabolic processes in every living cell with considerable specificity and selectivity as components of enzymes and other molecules complexes. These metals have to be maintained at a fixed level to avoid any toxic effects. Metal homeostasis imbalance and neuronal loss are both present in neurodegenerative diseases [23]. To gain new insights into the mechanisms underlying the brain membrane damage mediated trace metal disturbances caused by $\mathrm{TiO}_{2}$ NPs, this study was aimed to investigate the penetration of $\mathrm{TiO}_{2}$ NPs and further biochemical changes in the brain by administering $\mathrm{TiO}_{2} \mathrm{NPs}$ through intragastric route to Wistar rats, by assessing the changes in membrane-bound enzymes, and trace metals in different brain regions.

\section{MATERIALS AND METHODS}

Chemicals and dose preparation

$\mathrm{TiO}_{2}$ NPs (CAS NO: 13463-67-7) used in the present study was purchased from Sigma-Aldrich Chemicals Co. (St, Louis, MO 63103, 
USA). The crystal profile as characterized by automatic X-ray diffractometer (XRD, PANlytical XPERT-PRO) equipped with 240 mmradius goniometer. The data were collected in the mode of continuous scanning with a power setting of $40 \mathrm{kV}, 30 \mathrm{~mA}$, scanning speed of $10 \% / \mathrm{sec}$ using $\mathrm{Cu} \mathrm{K} \alpha$ radiation $(\lambda=0.154 \mathrm{~nm}) . \mathrm{TiO}_{2}$ nanoparticles were suspended in water and ultrasonicator for 5-20 min. The suspension was dipped on the cleaned silicon wafer and dried in an oven at $45^{\circ} \mathrm{C}$. The morphology and particle size of $\mathrm{TiO}_{2}$ nanoparticles were obtained with a high-resolution transmission electron microscopy (TEM, FEI Tecnai G2 F30S-Twin microscope).

A $0.9 \%$ saline solution $(\mathrm{NaCl})$ was used as a suspending agent. $\mathrm{TiO}_{2} \mathrm{NPs}$ suspension was prepared using physiological saline solution. The

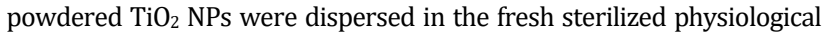
saline solution, and the suspension was ultrasonicated for 15-20 min and mechanically vibrated for 2-3 min to get a homogenous suspension and to disperse completely as much as possible.

\section{Animals and treatment}

Healthy adult male albino rats of Wistar strain (Rattus norvegicus) weighing 250-260 g obtained from the central animal house, central siddha research institute, Chennai were used for the present investigation. The animals were fed ad libitum with standard pellet diet and had free access to drinking water. All experimental and protocols described in the present study was approved by the institutional animal ethics committee (IAEC Approval No. 138/PHARMA/SCRI, 2013) and are in accordance with guidelines as per "guide for the care and use of laboratory animals" published by NIH publication (NO 85-23 revised 1996) and with permission from committee for the purpose of control and supervision of experiments on animals (CPCSEA), Ministry of Social Justice and Empowerment, Government of India.

Animals were randomly divided into three groups.

Group I-Control: Rats were given a normal saline solution as vehicle orally by gavage, daily for $14 \mathrm{~d}$.

Group II- $\mathrm{TiO}_{2}$ NPs treatment: Rats were treated with $\mathrm{TiO}_{2}$ NPs dissolved in normal saline solution at a dose of $50 \mathrm{mg} / \mathrm{kg}$ body weight daily for $14 \mathrm{~d}$, orally by gavage.

Group III- $\mathrm{TiO}_{2}$ NPs treatment: Rats were treated with $\mathrm{TiO}_{2}$ NPs dissolved in normal saline solution at a dose of $100 \mathrm{mg} / \mathrm{kg}$ body weight daily for $14 \mathrm{~d}$, orally by gavage.

At the end of the experiment, in order to maintain comparable conditions blood samples are usually collected at the morning after an overnight fasting. The fixed time schedule eliminates the possible effect of diurnal variations. $24 \mathrm{~h}$ after the experimental period the animals were sacrificed by cervical decapitation. Blood was collected separately for serological and haematological analyses. Brain was removed, cleared off the adhering tissues and weighed. Brain was dissected out; cerebrum, cerebellum and medulla oblongata were separated and processed immediately for biochemical and histological analysis. All the biochemical estimations were carried out by standard spectrophotometric techniques.

\section{Membrane-bound enzymes assay}

The brain samples were cooled in ice-cold, $50 \mathrm{mmol}$ Tris-HCl buffer (pH 7.55) and homogenized. The homogenate was centrifuged for 10 min at $3000 \mathrm{rpm}$, the supernatant was used for the assay of ATPases, ALP, $5^{\prime}$-NT and GGT.

The ATPases activity estimated according to the method of Takeo and Sakanashi, [24]. The activities of total, $\mathrm{Na}^{+} / \mathrm{K}^{+}, \mathrm{Mg}^{2+}$ and $\mathrm{Ca}^{2+}$ ATPases were determined using appropriate inhibitors of ATP; the inorganic phosphate liberated was estimated by the method of Fiske and Subbarow, [25]. Appropriate standard (sodium dihydrogen phosphate) was also run in each batch of the assay. The non-specific activity was subtracted from each activity detected. The enzyme activity was calculated from the standard graph. The enzyme activity is expressed as units/mg protein.

The activity of ALP was assayed by the method of Bessey et al. [26]. Each $0.5 \mathrm{ml}$ reaction mixture contained $0.5 \mathrm{ml}$ of glycine buffer and the mixture was placed in a water bath at $37{ }^{\circ} \mathrm{C}$ for 5 min. exactly after $30 \mathrm{~min}$, the reaction was arrested by the addition of $10 \mathrm{ml}$ of sodium hydroxide. The colour developed was read at $410 \mathrm{~nm}$, in a spectrophotometer. $0.1 \mathrm{ml}$ of concentrated HCL was added, mixed and the optical density was read at $400 \mathrm{~nm}$. The ALP activity was calculated from the calibration curve obtained using paranitrophenol standard. ALP activity is expressed as units/mg protein.

5'-NT was assayed following the method of Gerlach and Hiby, [27]. The activity of 5 '-NT was measured by the selective complete inhibition of the enzymes by nickel ions. The assay is carried out in the presence and absence of nickel ions, in their presence the activity of nonspecific phosphatase was determined, while in their absence the sum of the activity of nonspecific phosphatase and 5'-NT was measured. The difference in the amount of phosphate ion liberated per unit in the two assays is a measure of 5'-NT activity expressed as units/mg protein.

The GGT activity was estimated by the colorimetric method of Orlowski and Meister, [28]. The enzyme catalyses the transfer of $\gamma$-glutamyl groups from $\gamma$-glutamyl donors to the amino acids, peptide or water. The sample contains $0.5 \mathrm{ml}$ of the substrate, $1 \mathrm{ml}$ Tris-HCl buffer and $2.2 \mathrm{ml}$ glycylglycine. $0.2 \mathrm{ml}$ of enzyme solution was added to the above mixture then incubated. After incubation for $30 \mathrm{~min}$ at $37^{\circ} \mathrm{C}$, the reaction was arrested by the addition of $1 \mathrm{ml}$ of $10 \%$ acetic acid to the test and control tubes. The control tubes received substrate after incubation. Standard pnitroaniline was also treated similarly. The amount of liberated pnitroaniline in the supernatant was with and without the substrate. The substrate incubated in the absence of enzyme under the same condition was used as a reference blank. The enzyme activity was expressed as micromoles of p-nitroaniline formed $/ \mathrm{min} / \mathrm{mg}$ protein of tissue extract.

\section{Metal content analysis}

Approximately $0.2-0.3 \mathrm{~g}$ of tissues were weighed, digested and analyzed form metal contents. Briefly, prior to elemental analysis, these tissues were digested with ultrapure grade nitric acid overnight. After adding $0.5 \mathrm{ml}$ hydrogen peroxide $\left(\mathrm{H}_{2} \mathrm{O}_{2}\right)$, the mixed solutions were placed at $160{ }^{\circ} \mathrm{C}$ with high-pressure reaction containers in an oven-chamber until the samples were completely digested. Then, the solutions were incubated at $120^{\circ} \mathrm{C}$ to remove the remaining nitric acid until the solutions were colourless and clear. Finally, the remaining solutions were diluted to $3 \mathrm{ml}$ with $2 \%$ nitric acid. Inductively coupled plasma-mass spectrometry (ICP-MS) (Agilent 7500 CE, USA) was used to determine the titanium concentration in the samples. Indium $20 \mathrm{ng} / \mathrm{ml}$ was chosen as an internal standard element. The detection limit of titanium was 0.074 $\mathrm{ng} / \mathrm{ml}$. Data are expressed as nanograms per gram tissue.

\section{Histological examination}

For histology, Different brain regions were fixed for $48 \mathrm{~h}$ in $10 \%$ formalin-saline and dehydrated bypassing successfully through different mixtures of ethyl alcohol, cleaned in xylene and embedded in paraffin wax. Sections of the tissue (5-6 $\mu \mathrm{m}$ thick) were prepared using a rotary microtome, stained with haematoxylin and eosin (HandE) dye and then mounted in a neutral deparaffinized xylene medium for microscopic examination.

\section{Statistical analysis}

The data were subjected to statistical analysis using one-way analysis of variance (ANOVA) according to Zar, [29]. When the F test was found to be significant, the data were subjected to StudentNewman-Keuls (SNK) test to assess the significance of individual variations between the treatment groups.

\section{RESULTS}

\section{Characterization of $\mathrm{TiO}_{2}$ nanoparticles}

The microstructure, morphology, particle size and crystal profile of $\mathrm{TiO}_{2}$ nanoparticles were characterized by XRD and subsequent observation by TEM (fig. 1). The crystalline structure of $\mathrm{TiO}_{2}$ nanoparticles is clearly evident from the observation by TEM (fig. 1A). It is well evident from the XRD characterization the particle size of the $\mathrm{TiO}_{2}$ nanoparticles used in this study is having the size 33.95 nm (fig. 1B). 

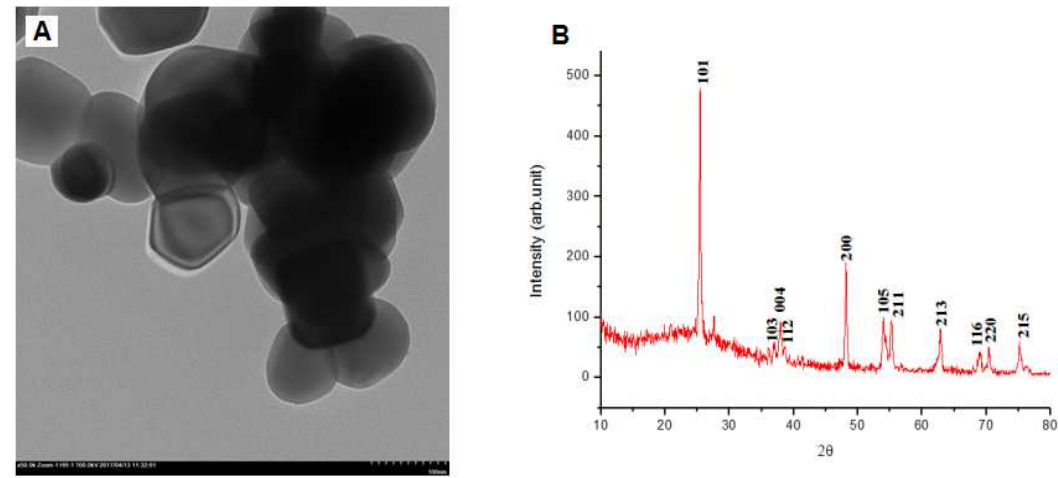

Fig. 1: Morphology and microstructure characterized by TEM (A) and X-ray diffraction pattern (B) of $\mathrm{TiO}_{2}$ nanoparticles

\section{Membrane-bound enzymes}

Fig. 2(A) shows the activity of $\mathrm{Ca}^{2+}$ dependent ATPase in cerebrum, cerebellum and medulla oblongata of the control and experimental rats. In $50 \mathrm{mg} \mathrm{\textrm {TiO } _ { 2 }} \mathrm{NPs}$ exposed rat group, a major inhibition of $\mathrm{Ca}^{2+}$ dependent ATPase activity was observed in the cerebellum $(p<0.001)$ followed by medulla oblongata $(p<0.01)$ and cerebrum $(p<0.05)$. In $100 \mathrm{mg} \mathrm{\textrm {TiO } _ { 2 }} \mathrm{NPs}$ treated group, the activity of $\mathrm{Ca}^{2+}$ dependent ATPase was significantly inhibited $(p<0.001)$ in all the three regions. The reduction of this enzyme due to $\mathrm{TiO}_{2} \mathrm{NPs}$ exposure is more and almost same $(34 \%)$ in cerebellum and medulla oblongata when compared to cerebrum where the reduction was only $27 \%$.

Fig. 2(B) shows the activity of $\mathrm{Mg}^{2+}$ dependent ATPase in control and experimental rats exposed to $\mathrm{TiO}_{2} \mathrm{NPs}$. The activity of $\mathrm{Mg}^{2+}$ dependent ATPase was significantly decreased in the cerebrum $(p<0.01)$ and cerebellum $(p<0.05)$ of $50 \mathrm{mg} \mathrm{TiO} 2 \mathrm{NPs}$ treated groups whereas, no significant change was observed in medulla oblongata. In $100 \mathrm{mg}$ treated group a noteworthy reduction $(p<0.001)$ was observed in all the three regions. The reduction of this enzyme due to $\mathrm{TiO}_{2} \mathrm{NPs}$ exposure is almost same in cerebellum and medulla oblongata $(27 \%)$ when compared to cerebrum where the reduction was only $22 \%$.

A

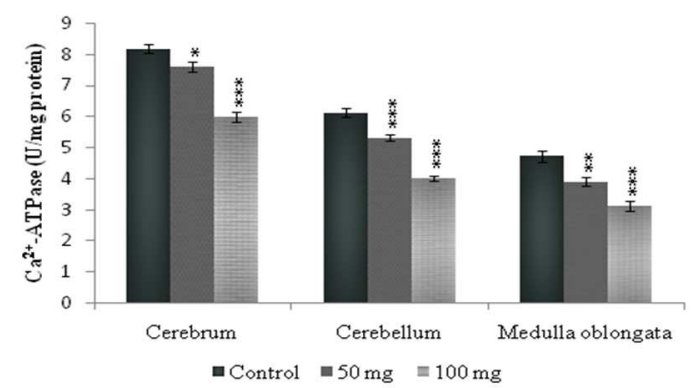

B

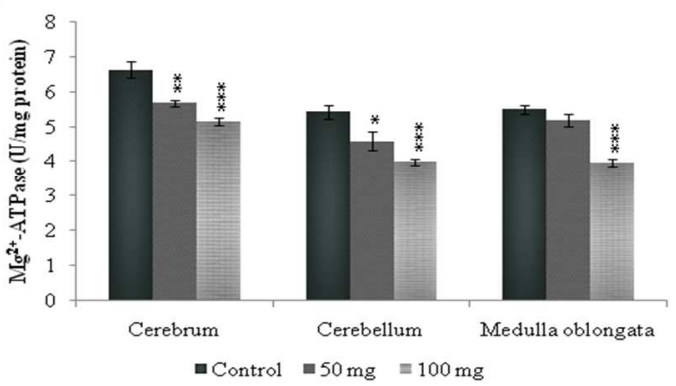

C

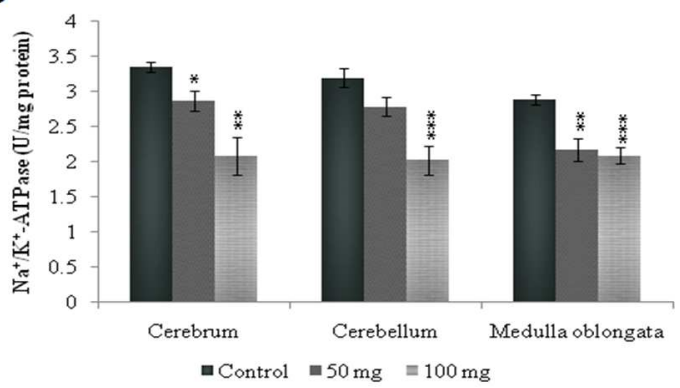

Fig. 2: Activities of $\mathrm{Ca}^{2+} \mathrm{ATPase}(\mathrm{A}), \mathrm{Mg}^{2+} \mathrm{ATPase}$ and $\mathrm{Na}^{+} / \mathrm{K}^{+} \mathrm{ATPase}$ in the cerebrum, cerebellum and medulla oblongata of rats exposed to 50 and $100 \mathrm{mg} / \mathrm{kg} \mathrm{b}$. $\mathrm{w}$ of $\mathrm{TiO}_{2} \mathrm{NPs}$ for $14 \mathrm{~d}$. The results are expressed as mean $\pm \mathrm{SEM}(\mathrm{n}=6)$ per treatment and respective control groups. Levels of significance values are ${ }^{*} p<0.05,{ }^{* *} p<0.01$ and ${ }^{* * *} p<0.001$ compared with control group. ${ }^{*} p<0.05$ considered to be statistically significant 
Fig. 2(C) shows the effect of $\mathrm{TiO}_{2} \mathrm{NPs}$ on the activities of $\mathrm{Na}^{+} / \mathrm{K}^{+}$ dependent ATPase in control and experimental rat groups. In $50 \mathrm{mg}$ exposed rats, the activity of $\mathrm{Na}^{+} / \mathrm{K}^{+}$dependent ATPase was significantly reduced only in the cerebrum $(p<0.05)$ and medulla oblongata $(p<0.01)$, while there were no significant changes observed in the cerebellum. On other hand, in $100 \mathrm{mg}$ administered group much more reduction of the activity of $\mathrm{Na}^{+} / \mathrm{K}^{+}$dependent ATPase in the cerebellum $(p<0.001)$ and medulla oblongata $(p<0.001)$ followed by cerebrum $(p<0.01)$ was noticed. The reduction of this enzyme almost same in cerebrum and cerebellum (37\%) when compared to medulla oblongata where the decrement was only $27 \%$.

Fig. 3(A) shows the activity of ALP in the brain of rats treated with $\mathrm{TiO}_{2}$ NPs. The activity of ALP is significantly reduced in the cerebrum $(p<0.01)$ and cerebellum $(p<0.001)$, whereas this enzyme activity was unaltered in the medulla oblongata of $50 \mathrm{mg} \mathrm{\textrm {TiO } _ { 2 }} \mathrm{NPs}$ treated group. The ALP activity was further reduced in $100 \mathrm{mg}$ treated group in all the three regions $(p<0.001)$.

The changes in the activity of 5'-NT of rat cerebrum, cerebellum and medulla oblongata is shown in fig. 3(B). In cerebrum and medulla oblongata regions, the activity of 5'-NT was not influenced significantly by $\mathrm{TiO}_{2}$ NPs in both the experimental groups. Interestingly, this enzyme activity was significantly decreased $(p<0.01)$ in the cerebellum of $100 \mathrm{mg}$ treated group.

The result presented in the fig. 3(C) indicates the activity of GGT in the control and experimental rats. $\mathrm{TiO}_{2} \mathrm{NPs}$ did not alter the GGT activity in medulla oblongata exposed for $50 \mathrm{mg}$ treated group, whereas significant reduction $(p<0.01)$ was observed in cerebrum and cerebellum of the same group. In $100 \mathrm{mg} \mathrm{\textrm {TiO } _ { 2 }} \mathrm{NPs}$ exposed group the activity was significantly reduced in the cerebrum $(p<0.001)$, medulla oblongata $(p<0.01)$ followed by cerebellum $(p<0.05)$.
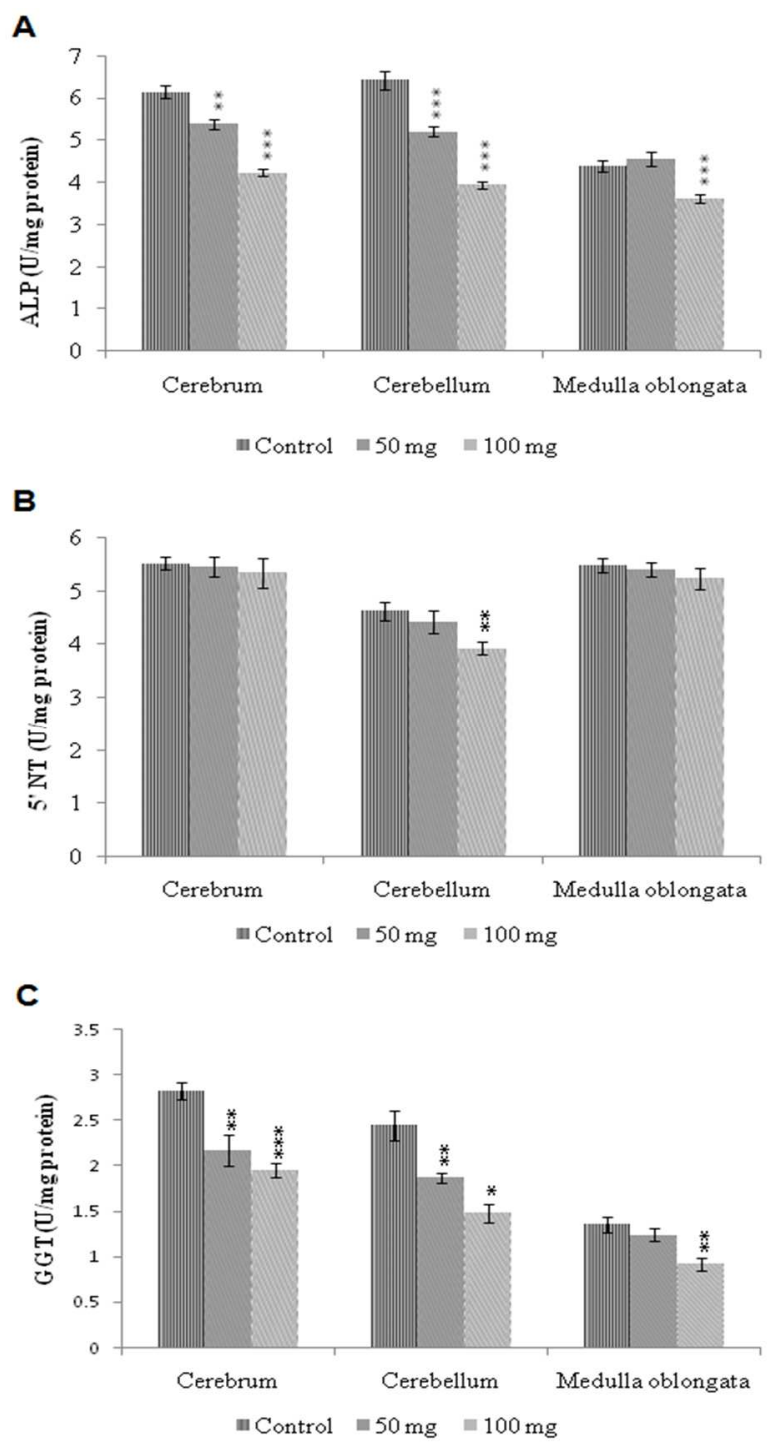

Fig. 3: Activities of ALP (D), 5'NT (E) and GGT (F) in the cerebrum, cerebellum and medulla oblongata of rats exposed to 50 and $100 \mathrm{mg} / \mathrm{kg}$ b. $w$ of $\mathrm{TiO}_{2} \mathrm{NPs}$ for $14 \mathrm{~d}$. The results are expressed as mean $\pm \operatorname{SEM}(n=6)$ per treatment and respective control groups. Levels of significance values are ${ }^{*} p<0.05,{ }^{* *} p<0.01$ and ${ }^{* * *} p<0.001$ compared with control group. ${ }^{*} p<0.05$ considered to be statistically significant

\section{Metal content analysis}

The contents of brain elements such as $\mathrm{Ca}, \mathrm{Mg}, \mathrm{Na}, \mathrm{K}, \mathrm{Zn}, \mathrm{Fe}$ and $\mathrm{Cu}$ were determined. The contents of $\mathrm{Ca}, \mathrm{Mg}, \mathrm{Na}, \mathrm{K}, \mathrm{Zn}$ and $\mathrm{Fe}$ in rat brain regions are listed in table 1 . It can be seen that exposure toTiO $\mathrm{TPS}_{2}$ has obviously changed the trace metal contents in the rat brain regions of cerebrum cerebellum and medulla oblongata. Increased contents of $\mathrm{Ca}, \mathrm{Na}, \mathrm{Fe}$ and $\mathrm{Cu}$ were found in different brain regions, while the contents of $\mathrm{K}, \mathrm{Mg}$ and $\mathrm{Zn}$ were decreased in the same regions of brain from $\mathrm{TiO}_{2} \mathrm{NPs}$ treated groups than those of the control. 
Table 1: Effect of $\mathrm{TiO}_{2} \mathrm{NPs}$ on metal contents different regions of the adult male wistar rats

\begin{tabular}{|c|c|c|c|c|}
\hline $\begin{array}{l}\text { Metal contents } \\
(\mu \mathrm{g} / \mathrm{g} \text { tissue })\end{array}$ & Experimental groups & Cerebrum & Cerebellum & Medulla oblongata \\
\hline \multirow[t]{3}{*}{$\mathrm{Ca}$} & Control & $175.40 \pm 7.57$ & $156.80 \pm 7.08$ & $138.70 \pm 6.94$ \\
\hline & 50 mg/kg b. w. & $228.80 \pm 10.08^{* *}$ & $189.09 \pm 9.94 *$ & $149.90 \pm 6.37$ \\
\hline & $100 \mathrm{mg} / \mathrm{kg} \mathrm{b.} \mathrm{w.}$ & $238.20 \pm 11.78^{* *}$ & $231.30 \pm 11.85^{* * *}$ & $165.20 \pm 7.89^{*}$ \\
\hline \multirow[t]{3}{*}{$\mathrm{Na}$} & Control & $167.60 \pm 7.17$ & $156.00 \pm 5.94$ & $137.20 \pm 5.83$ \\
\hline & 50 mg/kg b. w. & $194.40 \pm 8.39 *$ & $182.70 \pm 7.15^{*}$ & $172.10 \pm 6.31$ \\
\hline & $100 \mathrm{mg} / \mathrm{kg} \mathrm{b.} \mathrm{w.}$ & $203.70 \pm 8.65^{* *}$ & $183.30 \pm 7.72^{*}$ & $171.20 \pm 6.79 * *$ \\
\hline \multirow[t]{3}{*}{$\mathrm{K}$} & Control & $2213.90 \pm 95.59$ & $2247.50 \pm 101.50$ & $1986.90 \pm 89.97$ \\
\hline & $50 \mathrm{mg} / \mathrm{kg} \mathrm{b.} \mathrm{w.}$ & $1910.00 \pm 78.78^{*}$ & $1908.00 \pm 76.53^{*}$ & $1668.30 \pm 69.08^{*}$ \\
\hline & $100 \mathrm{mg} / \mathrm{kg} \mathrm{b.} \mathrm{w.}$ & $1903.70 \pm 78.57$ & $1883.70 \pm 78.33^{*}$ & $1663.70 \pm 61.86^{*}$ \\
\hline \multirow[t]{3}{*}{$\mathrm{Mg}$} & Control & $624.70 \pm 24.77$ & $596.00 \pm 23.43$ & $398.00 \pm 14.44$ \\
\hline & 50 mg/kg b. w. & $608.40 \pm 22.93$ & $499.40 \pm 21.07 *$ & $366.40 \pm 11.83$ \\
\hline & $100 \mathrm{mg} / \mathrm{kg} \mathrm{b.} \mathrm{w.}$ & $573.80 \pm 21.07$ & $429.90 \pm 18.54^{* * *}$ & $365.20 \pm 12.00$ \\
\hline \multirow{3}{*}{$\mathrm{Fe}$} & Control & $133.20 \pm 7.39$ & $129.90 \pm 7.26$ & $108.60 \pm 5.16$ \\
\hline & $50 \mathrm{mg} / \mathrm{kg} \mathrm{b.} \mathrm{w.}$ & $164.90 \pm 7.69^{*}$ & $169.70 \pm 7.43^{* *}$ & $126.90 \pm 6.96$ \\
\hline & $100 \mathrm{mg} / \mathrm{kg} \mathrm{b.} \mathrm{w.}$ & $165.00 \pm 7.64^{*}$ & $171.60 \pm 7.82^{* *}$ & $158.60 \pm 6.89^{* * *}$ \\
\hline \multirow[t]{3}{*}{$\mathrm{Zn}$} & Control & $94.40 \pm 4.53$ & $86.20 \pm 4.29$ & $64.60 \pm 3.66$ \\
\hline & 50 mg/kg b. w. & $80.60 \pm 3.78^{*}$ & $71.60 \pm 3.34^{*}$ & $48.10 \pm 2.72^{* *}$ \\
\hline & $100 \mathrm{mg} / \mathrm{kg} \mathrm{b.} \mathrm{w.}$ & $75.50 \pm 3.14^{* *}$ & $70.40 \pm 2.75^{*}$ & $47.50 \pm 2.28^{* *}$ \\
\hline \multirow[t]{3}{*}{$\mathrm{Cu}$} & Control & $12.10 \pm 0.56$ & $16.30 \pm 0.86$ & $9.00 \pm 0.49$ \\
\hline & $50 \mathrm{mg} / \mathrm{kg}$ b. w. & $16.10 \pm 0.74^{* *}$ & $22.30 \pm 0.96^{* * *}$ & $15.60 \pm 0.82^{* * *}$ \\
\hline & $100 \mathrm{mg} / \mathrm{kg} \mathrm{b.} \mathrm{w.}$ & $19.60 \pm 0.97^{* * *}$ & $25.00 \pm 1.04^{* * *}$ & $15.00 \pm 0.76^{* * *}$ \\
\hline
\end{tabular}

The results are expressed as mean $\pm \operatorname{SEM}(\mathrm{n}=6)$ per treatment and respective control groups. Levels of significance values are ${ }^{*} p<0.05,{ }^{* *} p<0.01$ and ${ }^{* * *} p<0.001$ compared with control group. ${ }^{*} p<0.05$ considered to be statistically significant.

Table 2: Titanium content in different regions of the rat brain after treatment

\begin{tabular}{llll}
\hline Ti (ng/g tissue) & Cerebrum & Cerebellum & Medulla oblongata \\
\hline Control & Not detected & Not detected & Not detected \\
$50 \mathrm{~m} / \mathrm{kg} \mathrm{b.} \mathrm{w.}$ & $173.20 \pm 8.16$ & $165.90 \pm 8.19$ & $149.90 \pm 4.40$ \\
$100 \mathrm{mg} / \mathrm{kgb} . \mathrm{w}$. & $225.60 \pm 12.66$ & $221.80 \pm 11.99$ & $160.90 \pm 6.68$ \\
\hline
\end{tabular}

The results are expressed as mean $\pm \operatorname{SEM}(n=6)$ per treatment and respective control groups. In control rats, titanium was not detected.
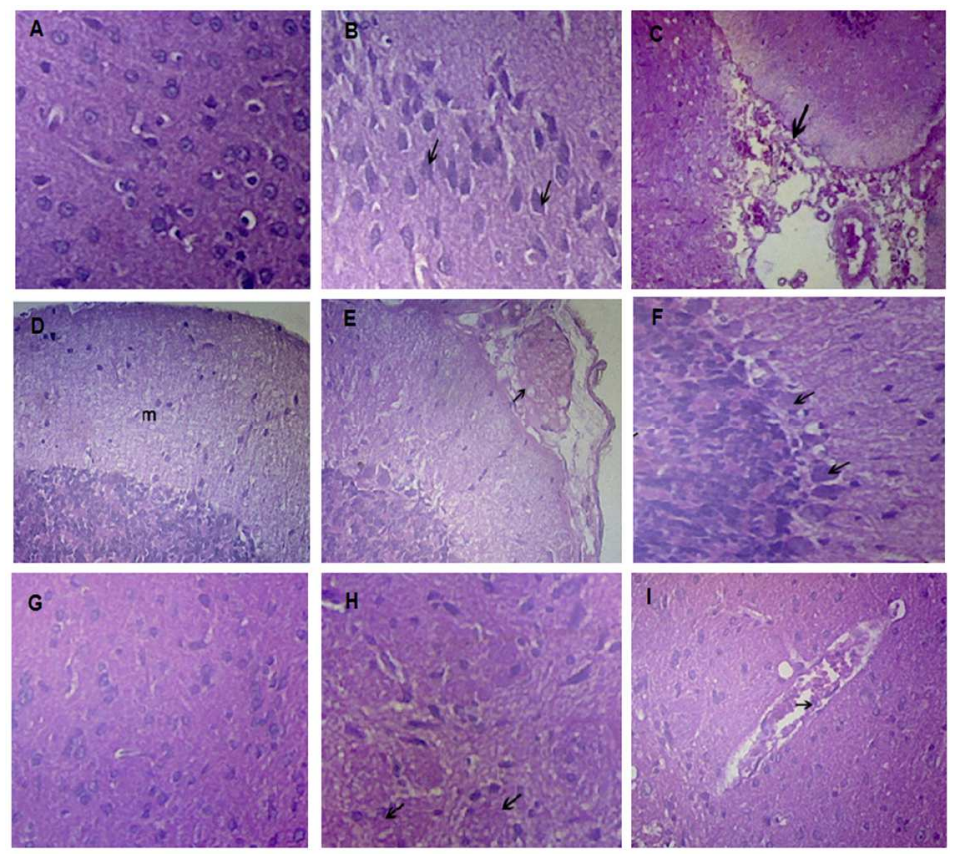

Fig. 4: Histology of the brain tissues (cerebrum, cerebellum and medulla oblongata) in rat caused by oral administration with $\mathrm{TiO}_{2} \mathrm{NPs}_{\mathrm{N}}$ for

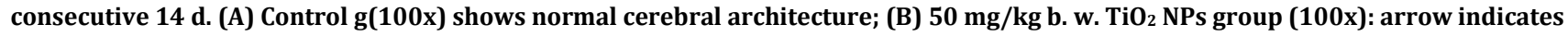
calcification deposition in neurocyte; suggesting too much of calcium depositing and accumulating in the cerebrum; (C) $100 \mathrm{mg} / \mathrm{kg} \mathrm{b}$. w. $\mathrm{TiO}_{2}$ NPs group (100x): arrow indicates ependyma proliferation; (D) control group (100x) shows normal cerebellum architecture and covering meninges (m); (E) $50 \mathrm{mg} / \mathrm{kg} \mathrm{b}$. w. TiO 2 NPs group (100x): arrow indicates congestion and oedema in meninges covering the cerebellum; (F) $100 \mathrm{mg} / \mathrm{kg} \mathrm{b}$. w. $\mathrm{TiO}_{2}$ NPs group (100x): arrow indicates degeneration in purkinje cells; (G) control group (100x) shows normal medulla oblongata architecture; $(\mathrm{H}) 50 \mathrm{mg} / \mathrm{kg} \mathrm{b}$. w. $\mathrm{TiO}_{2} \mathrm{NPs}$ group (100x): arrow indicates Axonal dystrophy, suggesting pathological changes of the neuron; (I) $100 \mathrm{mg} / \mathrm{kg} \mathrm{b}$. W. $\mathrm{TiO}_{2} \mathrm{NPs}_{\text {group }}(100 \mathrm{x})$ : arrow indicates Focal hemorrhage in the medulla oblongata. The section was stained with $\mathrm{H}$ and $\mathrm{E}$ and examined by light microscopy 


\section{Titanium content}

The content of titanium in the rat brain regions are shown in table 2 . With the increasing doses of $\mathrm{TiO}_{2} \mathrm{NPs}$, the titanium accumulation in cerebrum, cerebellum followed by medulla oblongata was elevated in both the groups, but not detected in control group.

\section{Histology observations of the brain regions}

Different regions of the brain histological pictures are illustrated in fig. 4. In the 50 and $100 \mathrm{mg} / \mathrm{kg} \mathrm{b}$. w. $\mathrm{TiO}_{2} \mathrm{NPs}$ treated groups, the brain tissues had abnormal pathological changes compared with the control, suggesting calcification of neurocyte in the cerebrum, which is a result of too much Ca depositing and accumulating in the brain, the proliferation of ependyma and spongiocyte, respectively (fig. 4B, $\mathrm{E}$ and $\mathrm{F}$ ). The generation of calcification and $\mathrm{Ca}$ depositions is confirmed by the assay of Ca content of brain regions.

\section{DISCUSSION}

Most toxicants interact with intracellular target molecules to cause changes in cellular metabolism and function, which eventually lead to cell membrane damage and cell lysis. Metal-induced plasma membrane damage occurs directly through interaction with membrane components such as ion-dependent ATPases and ion channels, and indirectly as a consequence of cytosolic damage [30].

The role of $\mathrm{Mg}^{2+} \mathrm{ATPase}$ is to maintain the high intracellular $\mathrm{Mg}^{2+}$ level in brain, changes of which can alter the rate of protein synthesis and cell growth [31]. $\mathrm{Mg}^{2+}$-ATPase is involved in ATP synthesis through oxidative phosphorylation in mitochondria [32]. The observed decrease in activity of $\mathrm{Mg}^{2+}$ ATPase in may hamper the ATP synthesis and thus can lead to mitochondrial disorganization [33].

$\mathrm{Ca}^{2+} \mathrm{ATPase}, \mathrm{a} \mathrm{Ca}{ }^{2+}$ binding protein and being crucial for maintenance of neuronal $\mathrm{Ca}^{2+}$ homeostasis [34], was significantly inhibited when exposed to $\mathrm{TiO}_{2} \mathrm{NPs}$. Calcium signalling is used by neurons to control a variety of functions, including cellular differentiation, synaptic maturation, neurotransmitter release, intracellular signalling, and cell death [35]. $\mathrm{Ca}^{2+}$-ATPase is a $\mathrm{Ca}^{2+}$ pump that transfers $\mathrm{Ca}^{2+}$ from the cytosol to the lumen of the endoplasmic reticulum at the expense of ATP hydrolysis. Therefore, it regulates the intracellular $\mathrm{Ca}^{2+}$ and, in turn, numerous cellular processes, such as exocytosis, cell proliferation, gene transcription, muscle contraction, and cell survival [36].

$\mathrm{Na}^{+}-\mathrm{K}^{+}$-ATPases play an important role in epithelial cell interaction and pathologies related with polarized epithelial cells and malignant tumors [37]. $\mathrm{Na}^{+} / \mathrm{K}^{+}$-ATPase is a key enzyme implicated in neural excitability, metabolic energy production [37]. This enzyme has a fundamental role in the regulation of epithelial cell morphology, signal transduction, and cell signalling [38]. $\mathrm{Na}^{+} / \mathrm{K}^{+}$-ATPase activity significantly decreased in the brain of $\mathrm{TiO}_{2} \mathrm{NPs}$ treated mice and it was suggested that $\mathrm{Na}^{+} / \mathrm{K}^{+}$-ATPase could not export intracellular redundant $\mathrm{Na}^{+}$and/or import extracellular $\mathrm{K}^{+}$timely. Decreased activity of $\mathrm{Na}^{+} / \mathrm{K}^{+}$-ATPase activity in the brain of $\mathrm{TiO}_{2} \mathrm{NPs}$ exposed rats, may reduce $\mathrm{Na}^{+}$and $\mathrm{K}^{+}$electrochemical gradient, disturbed ionic homeostasis and impair the physiological functions of neurons. In the present study, the altered activities of enzyme which are major biochemical component of cell membrane is suggestive of altered cellular proliferation and movement. It has been reported that metals interferes with the cell proliferation and cell migration [39].

ALP plays a crucial role in the metabolism of the CNS. ALP is associated with transmembrane transport mechanism, ion transport, maintenance of ionic strength and epithelial cell growth, differentiation and secretary activities [40]. ALP activity changes relatively under pathological conditions. In experimental brain wounds, high enzyme activity was reported in reorganizing capillaries at the borders of the lesion, in microglia cells, and in amorphous material within the brain wound [41]. It has been shown that the ALP is involved in the mediation of membrane transport and transphorylation [42]. The altered activity of ALP observed in the brain of $\mathrm{TiO}_{2} \mathrm{NPs}$ treated rats suggests cell damage in the brain. The decrease in the activity of ALP in the present study by administration of $\mathrm{TiO}_{2} \mathrm{NPs}$ could be attributed to either leakage of the enzyme into the extracellular fluid as a result of the disruption of the ordered lipid bilayer of the membrane or inhibition of the enzyme activity.
5'-NT is an established plasma membrane marker enzyme in many mammalian cells where it exists as an ectoenzyme [43]. The enzyme activity controls intracellular levels of nucleoside 5' monophosphates, and it is a major contributor to the cascade that completely hydrolyze extracellular ATP to adenosine, and thus of major pharmacological interest. Reduction in the activity of 5 -NT was found in metal-treated group compared to control group [44]. The inhibition of $5^{\prime}$-NT due to $\mathrm{TiO}_{2}$ exposure may result in a decrease in extracellular adenosine production.

GGT is also considered as a marker enzyme of cell membrane. GGT couples $\gamma$-glutamyl moiety to a suitable amino acid acceptor for transport into the cell and makes it suitable for the intracellular synthesis of GSH. GGT also mediates the cleaving of the dipeptidyl cysteinyl glycine, which provides cells with cysteine, a rate-limiting factor for the synthesis of GSH [45].

Trace elements are essential for normal brain structure and functions. Tiny amounts of these elements help in the formation of neurotransmitters and involved in the antioxidant defence and intracellular redox regulation and modulation of neural cells [46]. In the present study, $\mathrm{TiO}_{2} \mathrm{NPs}$ treatment increased Ca content in brain regions, which was consistent with the histological observation of the brain tissues. Brain injury involving in calcification and calcium deposition in neurocytes of $\mathrm{TiO}_{2}$ NPs exposed rats, which may indirectly or directly disturb the homeostasis of trace elements in brain as already suggested by Hu et al. [4]. Deficiency or excess of these metals resulted in central nervous system disorders [47] and pathological situation of the brain, such as neuronal injury, neurodegenerative diseases, and brain ischemia [48].

The present study shows the increased $\mathrm{Ca}$ and decreased $\mathrm{Zn}$ levels in various brain regions of rats exposed to $\mathrm{TiO}_{2} \mathrm{NPs}$. Thilsing-Hansen and Jørgensen, reported the antagonism between $\mathrm{Ca}$ and $\mathrm{Zn}$ in the brain following oral administration of $\mathrm{ZnO} \mathrm{NPs}$ [49]. In the present study also $\mathrm{TiO}_{2}$ NPs shows the antagonism between $\mathrm{Ca}$ and $\mathrm{Zn}$ in different regions of the brain. The changes in the $\mathrm{Ca}$ and $\mathrm{Zn}$ content caused by $\mathrm{TiO}_{2} \mathrm{NPs}$ can disturb the ion homeostasis and cause a series of physiological disorders in the CNS as it has been suggested earlier [34].

$\mathrm{Fe}$ as an important trace element is essential for neuron development and function. It is required for various physiological events including mitochondrial respiration, oxygen transport and DNA synthesis [50]. Furthermore, iron contributes to oxidative stress through Fenton reaction, leading to damages in DNA, proteins and membranes [51]. Fe imbalance is a precursor to the neurodegenerative processes leading to Alzheimer's disease (AD) and quantification of brain Fe content can be an effective marker for early diagnosis of $\mathrm{AD}$ [51]. In the present study, $\mathrm{TiO}_{2} \mathrm{NPs}$ treatment increased $\mathrm{Fe}$ content in different regions of rat brain. Excessive $\mathrm{Fe}$ would induce cell injury by reacting with $\mathrm{H}_{2} \mathrm{O}_{2}$ to produce hydroxyl radical $\left(\mathrm{OH}^{-}\right)$, superoxide anions $\left(\mathrm{O}^{2-}\right)$, and $\mathrm{ROS}$ [53]. The $\mathrm{Fe}$ overload in the brain may lead to neuron damage [54]. Fe is necessary in many cellular functions, especially in the brain, where it participates in many neuronal processes. In excess $\mathrm{Fe}$ is toxic to cells. The brain continuously accumulates $\mathrm{Fe}$, resulting in increased iron storage within the cell. This effect may lead to oxidative stress.

$\mathrm{Zn}$ is the second most abundant transition metal in the body [55], which is involved in the protection of BBB against oxidative stress of free radicals and essential for the synthesis of more than 300 coenzymes or metaloproteins that mediate biogenic amines synthesis and metabolism [56]. Zn level is essential to maintain homeostasis within the brain and prevent the development of neurological disorders [48]. A reduction in brain $\mathrm{Zn}$ content can impair the spatial memory in adult rats [57]. The observed reduction in the $\mathrm{Zn}$ content in different regions of the brain by $\mathrm{TiO}_{2}$ NPs may affect the function of $\mathrm{Zn}$ containing glutaminergic neurons and impairment of learning ability. This suggestion has already been put forth by Hu et al. in mice [4].

$\mathrm{Cu}$ is essential for normal CNS development and function, an essential cofactor in numerous enzymes, including cytochrome-coxidase $(\mathrm{CcO}), \mathrm{Cu} / \mathrm{Zn}$ superoxide dismutase $(\mathrm{Cu}, \mathrm{Zn}-\mathrm{SOD})$ and ceruloplasmin $(\mathrm{Cp})$ that play a central role for controlling the homeostasis of neurotransmitter and basic brain function [58]. The 
observed increased $\mathrm{Cu}$ level in the present study may disrupt the homeostasis in the brain and adverse effects in different regions of brain as it has also been shown in $\mathrm{Fe}_{2} \mathrm{O}_{3}$ NPs administered rats [59]. These findings support the hypothesis that neuronal cells from the brain regions of $\mathrm{TiO}_{2}$ NPs exposed rats undergo oxidative stress, which could ultimately lead to neurotoxicity as also suggested earlier $[4,60,61]$. The changes in electrochemical gradient and ionic homeostasis clearly indicate the damage to the brain of rats exposed to $\mathrm{TiO}_{2} \mathrm{NPs}$ subsequently affecting the CNS.

Metals primarily affect the mammalian brain and it has the capacity to damage the developing as well as the mature brain. The exact chemical mechanism by which $\mathrm{TiO}_{2}$ NPs influences brain is not clear. From this study, it is evident that $\mathrm{TiO}_{2} \mathrm{NPs}$ have a definite influence on membrane-bound enzymes and trace metals in the brain of male rats. The altered biochemical parameters strongly suggest the alteration in cell permeability, and possible cell injury and damage to CNS.

\section{CONCLUSION}

Our results clearly imply that orally ingested $\mathrm{TiO}_{2}$ NPscould impair the electrochemical gradient, ionic homeostasis and membrane stability in different regions of the rat brain. These changes may definitely have an adverse impact on CNS and associated functions. However, further approach at the molecular level is in progress which will through more light on this aspect.

\section{ACKNOWLEDGEMENT}

The authors are highly thankful to the Head of the Department of Zoology, Director, K. M. Centre for Post Graduate Studies, Puducherry and Research Officer, Department of Pharmacology, Director, Central Siddha Research Institute, Chennai, for providing all the facilities to carry out this work.

\section{AUTHORS CONTRIBUTIONS}

All the author have contributed equally

\section{CONFLICT OF INTERESTS}

None

\section{REFERENCES}

1. Wang J, Zhou G, Chen C, Yu H, Wang T, Ma Y, et al. Acute toxicity and biodistribution of different sized titanium dioxide particles in mice after oral administration. Toxicol Lett 2007;168:176-85.

2. Gandamalla D, Lingabathula H, Yellu NR. Cytotoxicity evaluation of titanium and zinc oxide nanoparticles on human cell lines. Int J Pharm Pharm Sci 2017;9:240-6.

3. Robichaud CO, Uyar AL, Darby MR, Zucker LG, Wiesner MR. Estimates of upper bounds and trends in nano- $\mathrm{TiO}_{2}$ production as a basis for exposure assessment. Environ Sci Technol 2009;43:4227-33.

4. Hu R, Gong X, Duan Y, Li N, Che Y, Cui Y, et al. Neurotoxicological effects and the impairment of spatial recognition memoryin mice caused by exposure to $\mathrm{TiO}_{2}$ nanoparticles. Biomaterials 2010;31:8043-50.

5. Zhang T, You L, Zhang Y. Photocatalytic reduction of pchloronitrobenzene on illuminated nano-titanium dioxide particles. Dyes Pigments 2006;68:95-100.

6. Oberdorster G, Oberdorster E, Oberdorster J. Nanotoxicology: an emerging discipline evolving from studies of ultrafine particles. Environ Health Perspect 2005;113:823-39.

7. Warheit DB, Hoke RA, Finlay C, Donner EM, Reed KL, Sayes CM. Development of a base of toxicity tests using ultrafine $\mathrm{TiO}_{2}$ particles as a component of nanoparticle risk management. Toxicol Lett 2007;171:99-110.

8. Grassian VH, O'Shaughnessy PT, Adamcakova-Dodd A, Pettibone JM, Thorne PS. Inhalation exposure study of titanium dioxide nanoparticles with a primary particle size of 2 to $5 \mathrm{~nm}$. Environ Health Perspect 2007;115:397-402.

9. Jia X, Wang S, Zhou L, Sun L. The potential liver, brain, and embryotoxicity of titanium dioxide nanoparticles on mice. Nanoscale Res Lett 2017;12:478.
10. Oberdorster G, Sharp Z, Atudorei V, Elder A, Gelein R, Kreyling $\mathrm{W}$, et al. Translocation of inhaled ultrafine particles to the brain. Inhal Toxicol 2004;16:437-45.

11. Chen HW, Su SF, Chien CT, Lin WH, Yu SL, Chou CC, et al. Titanium dioxide nanoparticles induce emphysema-like lung injury in mice. FASEB J 2006;20:2393-5.

12. Chen J, Dong X, Zhao J, Tang G. In vivo acute toxicity of titanium dioxide nanoparticles to mice after intraperitioneal injection. J App Toxicol 2009;29:330-7.

13. Liu H, Ma L, Zhao J, Liu J, Yan J, Ruan J. Biochemical toxicity of nano-anatase $\mathrm{TiO}_{2}$ particles in mice. Biol Trace Elem Res 2009;129:170-80.

14. Duan Y, Liu J, Ma L, Li N, Liu H, Wang J, et al. Toxicological characteristics of nanoparticulate anatase titanium dioxide in mice. Biomaterials 2010;31:894-9.

15. $\mathrm{Bu} \mathrm{Q}$, Yan G, Deng $\mathrm{P}$, Peng $\mathrm{R}$, Lin $\mathrm{H}, \mathrm{Xu} \mathrm{Y}$, et al. NMR-based metabonomic study of the sub-acute toxicity of titanium dioxide nanoparticles in rats after oral administration. Nanotechnology 2010;21:1-12.

16. Vasantharaja D, Ramalingam V, Reddy GA. Oral toxic exposure of titanium dioxide nanoparticles on serum biochemical changes in adult male Wistar rats. Nanomed J 2015;2:46-53.

17. Lockman PR, Koziara JM, Mumper RJ, Allen DD. Nanoparticle surface charges alter blood-brain barrier integrity and permeability. J Drug Target 2004;12:635-41.

18. Wu J, Liu W, Xue C, Zhou S, Lan F, Bi L, et al. Toxicity and penetration of TiO2 nanoparticles in hairless mice and porcine skin after subchronic dermal exposure. Toxicol Lett 2009;191:1-8.

19. Gao X, Yin S, Tang M, Chen J, Yang Z, Zhang W, et al. Effects of developmental exposure to $\mathrm{TiO}_{2}$ nanoparticles on synaptic plasticity in hippocampal dentate gyrus area: an in vivo study in anesthetized rats. Biol Trace Elem Res 2011;143:1616-28.

20. Long TC, Tajuba J, Sama P, Saleh N, Swartz C, Parker J, et al. Nanosize titanium dioxide stimulates reactive oxygen species in brain microglia and damages neurons in vitro. Environ Health Perspect 2007;115:1631-7.

21. Oszlanczi G, Horvath E, Szabo A, Horvath E, Sapi A, Gabor K, et al. Subacute exposure of rats by metal oxide nanoparticles through the airways: general toxicity and neuro-functional effects. Acta Biol Szegediensis 2010;54:165-70.

22. Sharma HS, Sharma A. Nanoparticles aggravate heat stressinduced cognitive deficits, blood-brainbarrier disruption, edema formation and brain pathology. Prog Brain Res 2007;162:245-73.

23. Buzea C, Pacheco II, Robbie K. Nanomaterials and nanoparticles: sources and toxicity. Biointerphases 2007; 2:17-71.

24. Takeo S, Sakanashi M. Characterization of membrane-bound adenosine triphophatase activity of enriched fraction from vascular smooth muscle. Enzyme 1985;34:152-65.

25. Fiske $\mathrm{CH}$, Subbarow Y. The colorimetric determination of phosphorous. J Biol Chem 1925;66:375-400.

26. Bessey OA, Lowery $\mathrm{OH}$, Brock MJ. A method for the rapid determination of alkaline phosphatase with fire cubic millimeters of serum. J Biol Chem 1946;164:321-30.

27. Gerlach U, Hiby W. 5' nucleodiase. In: Methods of enzymatic analysis, Bergmeyer HU. Eds. Vol. 2. Verlagchemie, Weinheim, Accademic Press: New York; 1974. p. 871-5.

28. Orlowski $\mathrm{M}$, Meister A. Isolation of gammaglutamyltranspeptidase from hog kidney. J Biol Chem 1965;240:338-47.

29. Zar JH. Biostatistical analysis. 1st edition. Prentice Hall, Eaglewood cliffs, Jersy, USA; 1974.

30. Chetty CS, Rajanna B, Rajanna S. Inhibition of rat brain microsomal $\mathrm{Na}^{+} / \mathrm{K}^{+}$-ATPase and brain binding by mercuric chloride. Toxicol Lett 1990;51:109-16.

31. Yallapragada PR, Vig PJ, Kodavanti PR, Desaiah D. In vivo effects of triorganotins on calmodulin activity in rat brain. J Toxicol Environ Health 1991;34:229-37.

32. Boyer PD, Chance B, Ernster L, Mitchell P, Racker E, Slater C. Oxidative phosphorylation and photophosphorylation. Ann Rev Biochem 1997;46:955-1026.

33. Pardini RS, Heidker JC, Baker TA, Payne B. Toxicology of various pesticides and their decomposition products on 
mitochondrial electron transport. Arch Environ Contam Toxicol 1980;9:87-97.

34. Parsons JT, Sun DA, De-Lorenzo R, Churn SB. Neuronal specific endoplasmic reticulum $\mathrm{Mg}^{2+} / \mathrm{Ca}^{2+}$-ATPase $\mathrm{Ca}^{2+}$ sequestration in mixed primary hippocampal culture homogenates. Anal Biochem 2004;330:130-9.

35. Mata AM, Sepulveda MR. Plasma membrane Ca-ATPases in the nervous system during development and ageing. World J Biol Chem 2010;1:229-34.

36. Clapham DE. Calcium signaling. Cell 2007;131:1047-58.

37. Abirami T, Jose AGR, Govindarajulu B, Karthikeyan J. Ecotoxicology of green synthesized silver nanoparticles on freshwater fish Mystus gulio. Int J Pharm Pharm Sci 2017; 9:192-8.

38. Kaplia AA, Morozova VS. $\mathrm{Na}^{+}, \mathrm{K}^{+}-\mathrm{ATPase}$ activity in polarized cells. Ukrainskii Biokhimicheskii Zhurnal 2010;82:5-20.

39. Choi KL, Aldrich RW, Yellen G. Tetraethyl ammonium blockade distinguishes two inactivation mechanisms in voltage-activated $\mathrm{K}^{+}$channels. Proc Natl Acad Sci USA 1991;88:5092-5.

40. Bannister RG, Romaul CA. The localization of alkaline phosphatase activity in cerebral blood vessels. J Neurol Neurosur Psychiatry 1963;26:333-40.

41. Naido D. Alkaline phosphate at the site of cerebral injury. Acta Histochem 1963;15:182-5.

42. Goldfischer SE, Novikoff AB. The localization of phosphatase activities at the level of ultrastructure. J Histochem Cytochem 1964;12:72-95.

43. Napieralski R, Kempkes B, Gutensohn W. Evidence for coordinated induction and repression of ecto-5"-nucleotidase (CD73) and the A2 an adenosine receptor in a human B cell line. Biol Chem 2003;384:483-7.

44. Zatta P, Lucchini R, Rnsburg SJ, Taylor A. The role of metals in the neurodegenerative process: aluminum, manganese, and zinc. Brain Res Bull 2003;62:15-28.

45. Pal R, Nath R, Gill KD. Lipid peroxidation and antioxidant defence enzymes in various regions of adult rat brain after coexposure to cadmium and ethanol. Basic Clin Pharmacol Toxicol 1993;73:209-14.

46. Fayed AH. Brain trace element concentration of rats treated with the plant alkaloid, vincamine. Biol Trace Elem Res 2010;136:314-9.

47. Madsen E, Gitlin JD. Copper and iron disorders of the brain. Ann Rev Neurosci 2007;30:317-7.
48. Konoha K, Sadakane Y, Kawahara M. Zinc neurotoxicity and its role in neurodegenerative diseases. J Health Sci 2006;52:1-8.

49. Thilsing Hansen T, Jørgensen RJ. Serum calcium response following oral zinc oxide administrations in dairy cows. Acta Veterinaria Scandinavica 2001;42:271-8.

50. Hentze MW, Mucknthaler MU, Andrews NC. Balancing acts: molecular control of mammalian iron metabolism. Cell 2004; 117:285-97.

51. Nappi AJ, Vass E. Iron, metalloenzymes and cytotoxic reactions. Cell Mol Biol 2002;4:637-47.

52. Smith MA, Zhu X, Tabaton M, Liu G, McKeel DW Jr, Cohen ML, et al. Increased iron and free radical generation in preclinical Alzheimer disease and mild cognitive impairment. J Alzheimers Dis 2010;19:363-72.

53. El-seweidy MM, El-Baky AE. Effect of dietary iron overload in rat brain: oxidative stress, neurotransmitter level and serum metal ion in relation to neurodegenerative disorders. Indian J Expert Biol 2008;46:855-8.

54. Won SM, Lee JH, Park UJ, Gwag J, Gwag BJ, Lee YB. Iron mediates endothelial cell damage and blood-brain barrier opening inthe hippocampus after transient forebrain ischemia in rats. Exp Mol Med 2011;43:121-8.

55. Raajshree KR, Durairaj B. Evaluation of the antityrosinase and antioxidant potential of zinc oxide nanoparticles synthesized from the brown seaweed-turbinaria conoides. Int J App Pharm 2017;9:116-20.

56. Nuttall JR, Oteiza PI. Zinc and the aging brain. Genes Nutr 2014;9:379.

57. Sandstead HH, Frederickson CJ, Penland JG. History of zinc as related to brain function. J Nutr 2000;130:496S-502S.

58. Que EL, Domaille DW, Change CJ. Metals in neurobiology: probing their chemistry and biology with molecular imaging. Chem Rev 2008;108:1517-49.

59. Wang B, Wnag Y, Feng W. Trace metal disturbance in mice brain after intranasal exposure of nano-and submicron-sized $\mathrm{Fe}_{2} \mathrm{O}_{3}$ particles. Chem Anal 2008;53:927-42.

60. Mohamed RH, Hussien NA. Genotoxicity studies of titanium dioxide nanoparticles $\left(\mathrm{TiO}_{2} \mathrm{NPs}\right)$ in the Brain of mice. Scientifica 2016;1-7. http://dx.doi.org/10.1155/2016/ 6710840.

61. Ma L, Liu J, Li N, Wang J, Duan Y, Yan J, et al. Oxidative stress in the brain of mice caused by translocated nanoparticulate $\mathrm{TiO} 2$ delivered to the abdominal cavity. Biomaterials 2010;31:99-105. 